\title{
DAMPAK PENDAYAGUNAAN DANA ZAKAT PRODUKTIF TERHADAP KEBERHASILAN USAHA KECIL MENENGAH MUSTAHIQ (STUDI KASUS LEMBAGA MANAJEMEN INFAQ MADIUN) ${ }^{1]}$
}

\author{
Akbar Nur Rulloh \\ Mahasiswa Program Studi Ekonomi Islam \\ Fakultas Ekonomi dan Bisnis Universitas Airlangga \\ Email: akbar.nur-12@feb.unair.ac.id \\ Suherman Rosyidi \\ Departemen Ekonomi Syariah \\ Fakultas Ekonomi dan Bisnis Universitas Airlangga \\ Email: suherman.rosyidi@feb.unair.ac.id
}

\begin{abstract}
This research aims to find out an impact of productive zakat fund utilization that has been given by Infaq Management Foundation to the success of business that has been being run by mustahiq. It is considered from the perspective of capital increase, revenue increase, production increase, consumer increase, and perpetual charity increase. The method used is qualitative-descriptive by case study method. The result of this research is those three informants have experienced capital increase, revenue increase, production increase, consumer increase, and also perpetual charity increase after they got productive zakat funding from LMI Madiun. This success could be considered from the increases of all indicators mentioned above. A high supervision that has been done by LMI Madiun is very useful to motivate and give spirit in maintaining business. Beside that, they are able to save some properties for those who have the right to it.
\end{abstract}

\section{Keywords : Productive Zakat, Venture Capital, Mustahiq, Utilization, Business Success}

\section{Pendahuluan}

\section{A. Latar Belakang}

Agama islam menjadi agama

untuk memberikan solusi atas rahmatan lil alamiin memerintahkan manusia untuk menjaga hubungan dengan Allah SWT maupun hubungan dengan sesama manusia dengan tujuan kebahagiaan dan kesejahteraan di dunia dan di akhirat. Secara sederhana hubungan dengan Allah SWT dapat diartikan bahwa seorang muslim harus secara tulus mengarahkan seluruh aktivitasnya kepada Allah SWT. Di sisi lain hubungan denga manusia dapat diartikan kepedulian sseorang terhadap orang lain. Kepedulian tersebut harus bagi seseorang muslim sehingga dia permasalahan umat termasuk kemiskinan.

Salah satu cara menanggulangi kemiskinan adalah dengan memanfaatkan dana zakat produktif. Zakat adalah sebagian harta milik seseorang yang Allah SWT mewajibkan pemiliknya untuk dikeluarkan dan diberikan kepada yang berhak menerima sesuai dengan syariat islam. Dengan dikeluarkan dan diberikanya dana zakat tersebut diharapkan mampu mengatassi masalah pemerataan pendapatan dan kemiskinan.

dapat memiliki rasa tanggung jawab

1] Jurnal ini merupakan bagian dari skripsi dari Akbar Nur Rulloh NIM: 041211431 163, yang diuji pada tanggal 14 Februari 2017 
Rulloh, et al/ Jurnal Ekonomi Syariah Teori dan Terapan Vol. 5 No. 3 Maret 2018: 184-199;

\section{DAMPAK PENDAYAGUNAAN DANA ZAKAT PRODUKTIF TERHADAP KEBERHASILAN USAHA KECIL} MENENGAH MUSTAHIQ (STUDI KASUS LMI MADIUN)

Dalam Al-Qur'an seringkali disebut kata zakat digabungkan dengan kata shalat. Hal ini menegaskan ada kaitan antara ibadah shalat dengan zakat. Jika shalat berdimensi vertikal ketuhanan, maka zakat merupakan ibadah horisontal kemanusian. Adapun ayat AlQur'an tentang pelaksanaan zakat tercantum dalam perintah Allah SWT surat At-Taubah ayat 103:

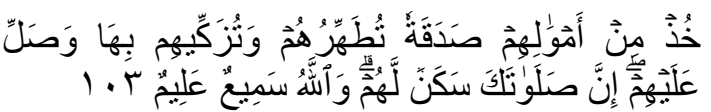

khudz min amwalihim sadaqatan tutahhiruhum watuzakkiihim biha wașalli 'alayhim inna șalataka sakanun lahum wa 'I-lahu samị'un 'alịmun Artinya "Ambillah zakat dari sebagian harta mereka, dengan zakat itu kamu membersihkan dan mensucikan mereka dan mendoalah untuk mereka. Sesungguhnya doa kamu itu (menjadi) ketenteraman jiwa bagi mereka. dan Allah Maha mendengar lagi Maha mengetahui"

Saat ini zakat tidak hanya dapat dimanfaatkan dalam kegiatan konsumtif, melainkan juga dapat dimanfaatkan dalam kegiatan produktif. Zakat produktif inilah yang akan membantu usaha para mustahik, tidak hanya dalam jangka pendek melainkan untuk jangka yang lebih panjang. Zakat yang pada mulanya hanya ditujukan untuk memberantas kemiskinan, menimbulkan pemikiran-pemikiran dan inovasi dalam penyaluran dana zakat itu sendiri. Salah satu buah pemikiran tersebut adalah diperkenalkan zakat sebagai bantuan dalam usaha produktif.
Sasono (1998:79) menjelaskan bahwa Keberadaan usaha kecil atau usaha mikro hendaknya dapat memberikan kontribusi yang cukup baik dalam menekan atau mengurangi kemiskinan dan pengangguran. Saat ini para pelaku usaha kecil atau usaha mikro masih banyak menghadapi permasalahan dalam mengakses modal. Dana zakat diberikan kepada mustahiq sebagai pendukung upaya-upaya yang di tujukan untuk meningkatkan pendayagunaan dan pengembangan dana zakat dalam bentuk modal usaha agar usaha kecil atau mikro dapat berkembang, sehingga penghasilan mustahiq dapat meningkat. Harapan yang terkandung dalam pemanfaatan dana zakat secara produktif ini adalah meningkatnya penghasilan mustahiq, sehingga kelak mereka bukan lag sebagai mustahiq melainkan sudah menjadi muzakki.

Hafidoh (2015: 6) menjelaskan bahwa Pengalokasian sebagaian dana zakat untuk kegiatan produktif melalui pemberian modal usaha. Praktek ini oleh lembaga amil zakat dengan mendampingi dan memberikan pengarahan kepada mustahik tersebut. Dengan upaya tersebut diharapkan usaha yang dijalankan mustahik dapat berkembang dan berjalan dengan lancar sehingga penghasilan mustahiq dapat meningkat. Sejalan dengan berkembangnya usaha, hal ini dapat mengurangi jumlah penganggur 
Rulloh, et al/ Jurnal Ekonomi Syariah Teori dan Terapan Vol. 5 No. 3 Maret 2018: 184-199;

DAMPAK PENDAYAGUNAAN DANA ZAKAT PRODUKTIF TERHADAP KEBERHASILAN USAHA KECIL MENENGAH MUSTAHIQ (STUDI KASUS LMI MADIUN)

sehingga konsumsi masyarakat terhadap suatu barang dan jasa meningkat dan meningkatkan daya beli masyarakat. Untuk meningkatkan konsumsi ini, kaum produsen akan meningkatkan produksi. Meningkatnya pertumbuhan produksi inilah yang akan menjadi salah satu indikator keberhasilan usaha mustahiq dalam memberdayakan dana zakat produktif.

Lembaga Manajemen Infaq (LMI) Madiun merupakan salah satu Lembaga Amil Zakat (LAZ) yang menghimpun dan menyalurkan dana zakat kepada masyarakat. Dalam pendayagunaan dana zakat produktif melalui pemberian modal usaha, LMI Madiun melakukan beberapa kegiatan untuk meningkatkan kesejahteraan hidup mustahik. Setelah diberi modal, mustahik dapat meningkatkan produksi sehingga dapat menambah penjualan dan akhirnya menambah pendapatan. Dengan kata lain, dengan pemberian modal tersebut diharapkan mustahik dapat mencapai keberhasilan usaha yang dijalankannya.

Berdasarkan uraian diatas, maka penulis tertarik meneliti lebih dalam mengenai : "Dampak Penayagunaan Dana Zakat Produktif Terhadap Keberhasilan Usaha Mustahia (Studi Kasus LMI Madiun)

\section{B. Rumusan Masalah}

Berdasarkan latar belakang permasalahan yang telah diuraikan di atas, maka rumusan masalah yang diangkat dalam penelitian ini yaitu :
"Bagaimana dampak pendayagunaan dana zakat produktif yang diberikan oleh Lembaga Manajemen Infaq (LMI) Madiun terhadap keberhasilan usaha mustahik?"

\section{C.Tujuan Penelitian}

Penelitian ini ditujukan untuk mengetahui seberapa besar dampak pendayagunaan dana zakat produkitf yang dialokasikan sebagai modal usaha oleh LMI Madiun yang dilihat dari peningkatan modal, peningkatan pendapatan, peningkatan produksi, peningkatan jumlah konsumen dan peningkatan amal jariyah mustahia setelah menerima dana zakat produktif.

\section{LANDASAN PUSTAKA}

\section{Zakat Produktif}

Keberadaan zakat kini tidak hanya untuk memenuhi kebutuhan konsumtif mustahiq semata. Shinta (2014:7) menjelaskan bahwa zakat yang memang pada mulanya ditujukan untuk memberantas kemiskinan menimbulkan pemikiran-pemikiran dan inovasi dalam penyaluran dana zakat itu sendiri, yang salah satunya adalah sebbagai bantuan dalam usaha produktif. Usaha produktif berkaitan dengan pembangunan dan pertumbuhan ekonomi pada khususnya serta meningkatkan kesejahteraan masyarakat. Zakat produktif juga digunakan untuk menstilmulus masyarakat agar memiliki keinginan berwirausaha dan dapat lebih mandiri dalam memenuhi kebutuhan sehari-hari. 
Rulloh, et al/ Jurnal Ekonomi Syariah Teori dan Terapan Vol. 5 No. 3 Maret 2018: 184-199;

\section{DAMPAK PENDAYAGUNAAN DANA ZAKAT PRODUKTIF TERHADAP KEBERHASILAN USAHA KECIL MENENGAH MUSTAHIQ (STUDI KASUS LMI MADIUN)}

Qadir (2011:46) menjelaskan "zakat produktif adalah zakat yang berupa modal usaha". Modal usaha tersebut digunakan untuk mejalankan suatu kegiatan ekonomi yaitu menumbuh kembangkan potensi produktivitas mustahiq. Dengan berkembangnya produktivitas mustahiq taraf hidup mustahiq akan meningkat, dan diharapkan dengan meningkatmya taraf hidup mustahiq itu kelak mustahiq tersebut akan menjadi muzzaki.

Qardhawi (1999:78) menjelaskan bahwa pemerintah Islam diperbolehkan membangun pabrik-pabrik atau perusahaan-perusahaan dari vang zakat yang kemudian keuntunganya untuk kepentingan fakir miskin. Pengembangan zakat dalam kegiatan produktif dengan cara menjadikanya sebagai modal usaha untuk pemberdayaan ekonomi bertujuan supaya fakir miskin dapat membiayai kehidupanya secara konsisten. Dengan dana zakat tersebut fakir miskin akan mendapatkan penghasilan yang tetap, dapat meningkatkan usaha, dapat mengembangkan usaha serta dapat pula menyisihkan sebagian harta untuk ditabung. Tujuan utama daari zakat produktif adalah terpenuhinya kebutuhan hidup mustahiq dalam waktu yang lama. Bahkan pengelolaan dana zakat secara produktif dapat menjadikan orang yang sebelumnya miskin menjadi seorang yang mandiri.
Dari beberapa penjelasan tentang zakat produktif yang telah diberikan, dapat disimpulkan bahwa zakat produktif adalah dana zakat yang diperuntukan untuk kegiatan produktif sehingga memberikan dampak jangka panjang bagi mustahiq, tidak hanya untuk sekali konsumsi saja. Salah satu penyaluran zakat produktif dapat dilakukan dengan memberikan modal usaha kepada mustahiq, memberikan pelatihan dan pendampingan dalam kegiatan usaha yang dijalan mustahiq.

\section{Zakat Produktif Sebagai Modal Usaha}

Fadhillah (2012:13) menjelaskan bahwa dalam setiap kegiatan ekonomi dibutuhkan modal untuk menjalakan usaha. Modal dalam pengertian ekonomi adalah barang yang bersama faktor produksi lain seperti tanah dan tenaga kerja yang dapat menghasilkan barang baru. Modal juga dapat diartikan pengeluaran untuk membeli barang-barang yang digunakan untuk proses produksi barang dan jasa yang kemudian dikonsumsi oleh konsumen

$\begin{array}{llr}\begin{array}{c}\text { Menurut } \\ \text { "pembiayan }\end{array} & \text { produktif } & \text { adalah } \\ \text { pembiayaan } & \text { yang ditujukan untuk } \\ \text { memenuhi } & \text { kebutuhan produksi". }\end{array}$
Kebutuhan produksi tersebut dalam arti luas yaitu untuk peningkatan usaha, baik usaha produksi, perdagangan maupun investasi. Berdasarkan jenis keperluanya, pembiayaan produktif dibagi menjadi dua yaitu : 
Rulloh, et al/ Jurnal Ekonomi Syariah Teori dan Terapan Vol. 5 No. 3 Maret 2018: 184-199;

DAMPAK PENDAYAGUNAAN DANA ZAKAT PRODUKTIF TERHADAP KEBERHASILAN USAHA KECIL MENENGAH MUSTAHIQ (STUDI KASUS LMI MADIUN)
1. Pembiayaan modal kerja yaitu pembiayaan untuk memenuhi kebutuhan produksi secara kuantitatif (jumlah hasil produksi) dan kualitatif (peningkatan kualitas produksi).

2. Pembiayan Investasi yaitu pembiayaan untuk memenuhi kebutuhan barang-barang modal serta fasilitas-fasiltas yang erat kaitanya dengan investasi

Zakat produktif diberikan sebagai tambahan modal yang disalurkan kepada mustahiq yang memiliki usaha. Zakat produktif yang disalurkan tersebut dapat berbagai macam bentuknya yaitu dapat berupa modal maupun dana juga digunakan dalam proses produksi usaha. Selain itu zakat produktif juga disalurkan berupa modal kerja seperti peralatan yang dapat dipakai untuk kegiatan produksi

\section{Pendayagunaan}

Pendayagunaan berasal dari kata "dayaguna," daya yang berarti kemampuan dan guna yang berarti manfaat. Pendayagunaan menurut Kamus Besar Bahasa Indonesia berarti 1) pengusahaan agar mampu mendatangkan hasil dan manfaat; 2) Pengusahaan (tenaga dan sebagainya) agar mampu menjalankan tugas dengan baik. Dapat disimpulkan bahwa pendayagunaan dana zakat merupakan serangkaian cara dalam pennyaluran dana zakat agar fungsi dan tujuan didistribusikan dana zakat tersebut dapat tercapai optimal dan mampu memenuhi kebutuhan mustahiq.

Pendayagunaan menajdi penting karena proses ini menjadi penentu keberhasilan pennyelesaian masalah yang ada pada mustahiq, sebab penyaluran zakat yang efektif dan tepat sasaran akan mengoptimalkan fungsi dan tujuan pendayagunaan zakat itu. Ada dua bentuk penyaluran dana zakat menurut Bariadi (2005:89) yaitu "sesaat dan pendayagunaan". Sesaat bahwa zakat diberikan kepada mustahia satu kali saja dan difungsikan untuk habis sekali pakai. Di sisi lain, pendayagunaan merupakan penyaluran zakat untuk usaha produktif yang disertai target merubah seorang mustahiq menjadi muzzaki. Merubah seorang mustahiq menjadi muzzaki ini tergolong tidak mudah dan membutuhkan waktu yang cukup lama. Mustahiq yang menerima dana zakat harus melewati fase pelatihan dan pendampingan untuk dapat menjadi mandiri dan kelak dapat meningkatkan derajatnya menjadi seorang muzakki.

Pendayagunaan dana zakat diharapkan mampu memberikan dampak positif bagi mustahiq, baik secara sosial maupun ekonomi. Secara sosial pendayagunaan dana zakat diharapkan mampu menjaga martabat dan kehormatan mustahia dari sikap meminta-minta dan mencegah terjadinya eksploitasi terhadap mustahiq untuk kepentingan yang menyimpang 
Rulloh, et al/ Jurnal Ekonomi Syariah Teori dan Terapan Vol. 5 No. 3 Maret 2018: 184-199;

DAMPAK PENDAYAGUNAAN DANA ZAKAT PRODUKTIF TERHADAP KEBERHASILAN USAHA KECIL MENENGAH MUSTAHIQ (STUDI KASUS LMI MADIUN)

serta dapat menjajarkan kedudukan

sosial mustahiq dengan masyarakat lain.

Secara ekonomi pendayagunaan dana zakat diharapkan mampu mengangkat derajat mustahiq menjadi muzzaki dan mampu menuntut mustahiq untuk hidup mandiri secara layak serta mampu meningatkan kesejahteraan hidup mustahiq. Hal ini berarti zakat tidak hanya didistribusikan untuk hal-hal yang bersifat konsumtif saja tetapi juga untuk kepentingan yang produktif dan bersifat edukatif.

\section{Keberhasilan Usaha}

Keberhasilan usaha pada hakikatnya adalah keberhasilan dalam mencapai tujuan dari bisnis. Primiani (2009:49) menyatakan bahwa suatu usaha dikatakan berhasil apabila telah memenuhi tiga unsur yaitu permodalan usaha sudah terpenuhi, penyaluran yang produktif dan tercapainya tujuan organisasi. Modal merupakan salah satu faktor terpenting dalam suatu bisnis. Modal digunakan untuk menjalankan kegiatan bisnis dan mengembangkanya serta memperluas pangsa pasar dari suatu bisnis. Selain telah memenuhi tiga hal unsur di atas Ryanti (2003: 29) menjelaskna bahwa seorang wirausaha harus inovatif, kreatif dan mengikuti perkembangan teknologi serta dapat menerapkannya secara proaktif. Mereka juga harus memiliki energi serta dorongan dan kemampuan asertif.

Suatu bisnis dikatakan berhasil apabila mendapatkan laba, karena laba adalah tujuan suatu bisnis. Selain laba, keberhasilan usaha dapat dilihat dari target yang dibuat oleh pengusaha. Noersasongko (2005:27) menjelaskan bahwa keberhasilan usaha dapat dianalisis dengan mengetahui kinerja suatu perusahaan yang dihasilkan dengan nilai yang diharapkan dengan memanfaatkan sumberdaya yang dimiliki. Kinerja usaha perlu dihubungkan dengan target usaha perusahaan yang ditentuka oleh pemilik usaha. Apapun targetnya, kinerja usaha merupakan tolok ukur untuk menilai seberapa besar tingkat pencapaian tujuan usaha.

Luk dalam Chamdan (2010:179) menjelaskan bahwa keberhasilan usaha kecil ditandai oleh inovasi dan perilaku dalam mengambil resiko. Berbagai faktor penentu keberhasilan usaha kecil pada dasarnya adalah cerminan dari kemampuan seorang pengusaha seperti pengetahuan, sikap, dan keterampilan dalam mengelola usahanya, pengalaman dan motivasi kerja serta tingkat pendidikanya.

Keberhasilan usaha tidak hanya dilihat dari hasil secara fisik tetapi keberhasilan usaha dirasakan oleh pengusaha dapat berupa kepuasana batin. Kepuasan batin dapat dirasakan dengan meningkatnya tingkat ibadah ritual maupun praktek agama sorang pengusaha serta kesadaran untuk sering bersedekah dan berbagi terhadap sesama.

\section{Indikator Keberhasilan Usaha}


Rulloh, et al/ Jurnal Ekonomi Syariah Teori dan Terapan Vol. 5 No. 3 Maret 2018: 184-199;

\section{DAMPAK PENDAYAGUNAAN DANA ZAKAT PRODUKTIF TERHADAP KEBERHASILAN USAHA KECIL MENENGAH MUSTAHIQ (STUDI KASUS LMI MADIUN)}

Keberhasilan usaha diidentifikasi dengan perkembangan perusahaan. Perkembangan perusahaan adalah proses dalam pertambahan jumlah karyawan, peningkatan modal dan lainlain. Dalam memperoleh keberhasilan usaha ada beberapa indikator yang harus dimiliki oleh pengusaha. Menurut Noor (2007:397) indikator dalam menentukan keberhasilan usaha ada lima yaitu laba, produktivitas dan efisiensi, daya saing, kompetensi dan etika usaha serta terbangunya citra baik. Laba merupakan tujuan utama dari bisnis. Besar kecilnya laba dipengaruhi oleh pendapatan yang diperoleh perusahaan. Pendapatan perusahaan diperoleh dari hasil barang produksi. Semakin besar tingkat penjualan barang produksi maka pendapatan yang diperoleh perusahaan semakin besar dan begitu pula sebaliknya. Dalam hal ini besar kecilnya produksi ditentukn oleh produktifitas suatu usaha.

Indikator keberhasilan usaha yang dijelaskan di atas, telah dirangkum oleh Ryanti (2003:28) yaitu :

1. peningkatan modal

2. peningkatan pendapatan

3. peningkatan produksi

4. peningkatan jumlah konsumen

Dalam penelitian ini indikator dalam menentukan keberhasilan usaha menggunakan pendapat Ryanti (2003:28) tersebut yaitu bahwa indikator keberhasilan usaha meliputi peningkatan modal, peningkatan pendapatan, peningkatan produksi dan pendapatan jumlah konsumen serta peningkatan amal jariyah mustahiq. Pendapat Ryanti ini dirasa cukup signifikan untuk menentukan keberhasilan usaha.

\section{METODOLOGI PENELITIAN}

\section{A. Pendekatan Penelitian}

Penelitian ini menggunakan pendekatan metode kualitatif deskriptif. Sugioyono (2011:9) menjelaskan sebagai berikut :

"penelitian kualitatif adalah metode penelitian yang berlandaskan pada sifat postpositivisme digunakan untuk meneliti pada kondisi obyek yang alamiah."

Penelitian ini menggunakan studi kasus deskriptif yang bertujuan untuk menjelaskan dan menggambarkan dampak pendayagunaan dana zakat produktif terhadap keberhasilan usaha mustahiq..

Salah satu metode penelitian sosial yang digunakan dalam penelitian ini adalah studi kasus. Yin (2009: 27) menjelaskan,

"the case study method is most likely to be appropriate for "how" and "why" questions, so your initial task is to clarify precisely the nature of your study questions in the regard".

Metode studi kasus bertujuan untuk menjawab pertanyaan "bagaimana" atau "mengapa" yang hanya dapat ditemukan jawabannya melalui pengamatan yang mendalam. Hal ini sesuai dengan rumusan masalah yang telah disusun sebelumnya.

Pemilihan metode penelitian harus dilakukan dengan tepat agar hasil 
Rulloh, et al/ Jurnal Ekonomi Syariah Teori dan Terapan Vol. 5 No. 3 Maret 2018: 184-199;

DAMPAK PENDAYAGUNAAN DANA ZAKAT PRODUKTIF TERHADAP KEBERHASILAN USAHA KECIL MENENGAH MUSTAHIQ (STUDI KASUS LMI MADIUN)

penelitian yang didapat sesuai dengan tujuan penelitian. Konsep studi kasus Yin dipilih sebagai konsep metode penelitian yang paling sesuai untuk membantu menghasilkan jawaban penelitian secara sistematik, akurat, dan sesuai dengan tujuan penelitian.

\section{B. Rancangan Penelitian}

Penelitian ini menggunakan desain studi kasus. Yin (2009: 29) menjelaskan sebagai berikut :

\section{A study's questions}

Perumusan masalah menggunakan pertanyaan "bagaimana" yang sesuai dengan defnisi Yin (2009:1) bahwa studi kasus adalah strategi yang cocok digunakan dalam penelitian yang pokok pertanyaanya adalah how dan why serta fenomena dalam konteks kehidupan nyata. Seperti dalam rumusan masalah penelitian ini yaitu "Bagaimana Dampak Pendayagunaan Dana Zakat Produktif Terhadap Keberhasilan Usaha Mustahiq?"

2. Studi Propositions

Pada proposisinya suatu penelitian mengerahkan perhatian peneliti kepada suatu yang harus diselidiki dalam ruang lingkup penelitian. Proposisi digunakan sebagai batasan suatu penyempitan data yang relevan. Proposisi yang digunakan pada penelitian ini adalah "Dana zakat produktif akan mampu memberikan dampak terhadap keberhasilan usaha di jalankan oleh mustahiq yang kemudian

menjadikan keberlangsungan usaha tersebut semakin baik dan produktif"

3. Unit of analysis

Unit analisis merupakan komponen yang berkaitan dengan masalah penentu kasus dalam penelitian ini. Kepustakaan terdahulu dapat menjadi tuntunan dalam menetapkan kasus dan unit analisis. Penentuan kasus dan unit analisis perlu mempehatikan peranan kepustakaan penelitian yang tersedia. Dalam penelitian ini, unit yang akan diteliti adalah keberhasilan usaha mustahiq yang meliputi peningkatan modal, peningkatan pendapatan, peningkatan produksi dan pendapatan jumlah konsumen serta peningkatan amal jariyah mustahiq

4. The logic linking the data to the propositions

Komponen ini mengetengahkan tahap-tahap analisis data dalam penelitian studi kasus. Pengaitan data terhadap proposisi dapat dilakukan dengan banyak cara, namun tidak ada satupun yang dapat terdefinisi secara pasti. Satu pendekatan yang memberi harapan kepada studi kasus adalah gagasan mengenai penjodohan pola yaitu mengaitkan beberapa informasi kasus yang sama. dengan beberapa proposisi teoritis

5. The criteria for interpreting the findings Komponen yang terkahir ini juga tidak memiliki satupun cara yang tepat yang dapat digunakan untuk menyusun kriteria guna menginterpretasikan tipe- 
Rulloh, et al/ Jurnal Ekonomi Syariah Teori dan Terapan Vol. 5 No. 3 Maret 2018: 184-199;

\section{DAMPAK PENDAYAGUNAAN DANA ZAKAT PRODUKTIF TERHADAP KEBERHASILAN USAHA KECIL} MENENGAH MUSTAHIQ (STUDI KASUS LMI MADIUN)

tipe data temuan. Fungsi kedua

komponen ini adalah untuk menindaklanjuti apa yang harus dilakukan setelah data terkumpul, seperti yang diterangkan oleh Yin (1998:33) "These components represent the data analysis steps in case study research, and a research design should lay the foundations for this analysis". Dengan demikian, kedua komponen ini tidak diikutsertakan dalam rancangan penelitian

\section{Ruang Lingkup Penelitian}

Ruang lingkup penelitian ini berkaitan erat dengan rumusan masalah dalam penelitian ini. Rumusan masalah dalam penelitian ini adalah "bagaimana dampak pendayagunaan dana zakat produktif terhadap keberhasilan usaha mushahiq pada lembaga manajemen infaq (LMI) Madiun". Berdasarkan rumusan masalah yang telah dipaparkan diatas, maka ruang lingkup penelitian ini mencakup 4 hal, antara lain:

1. Area.

Dalam penelitian ini area yang akan dijadikan tempat penelitian adalah Lembaga Manajemen Infaq (LMI) Madiun. Peneliti memilih LMI Madiun sebagai area penelitian karena pendayagunaan dana zakat produktif di kota Madiun yang pendistribusiannya disertai pembimbingan dan pengawasan kepada mustahik hanya ada di LMI Madiun, sedangkan Badan Amil
Zakat (BAZ) Madiun dan Lembaga Amil Zakat lainya memberikan dana zakat produktif tanpa memberikan bimbingan dan pengawasan.

2. Pelaku

Dalam penelitian ini yang dijadikan pelaku penelitian adalah kelompok mustahiq yang mendapatkan bantuan dana zakat produktif. Informan kelompok mustahia tersebut akan diwawancarai menggunakan ukuran indikator yang telah ditentukan, sehingga dapat diteliti lebih dalam untuk diketahui dampak dana zakat produktif terhadap keberhasilan usaha mustahiq.

3. Waktu

Dalam penelitian waktu yang digunakan oleh peneliti hanya terbatas pada mustahiq yang sudah mendapatkan bantuan dana zakat produktif pada periode saat ini serta masih dalam proses pengawasan, tidak pada mustahiq yang mendapatkan bantuan dana zakat produktif dan pengawasan yang sudah berlalu.

4. Keterbatasan Studi Penelitian ini adalah sebuah spot potrait, dengan demikian hasil penelitian ini tidak dapat dipakai untuk memprediksikan.

\section{Jenis dan Sumber Data}

Jenis dan sumber data penelitian merupakan salah satu faktor yang menjadi pertimbangan dalam 
Rulloh, et al/ Jurnal Ekonomi Syariah Teori dan Terapan Vol. 5 No. 3 Maret 2018: 184-199;

\section{DAMPAK PENDAYAGUNAAN DANA ZAKAT PRODUKTIF TERHADAP KEBERHASILAN USAHA KECIL MENENGAH MUSTAHIQ (STUDI KASUS LMI MADIUN)}

menentukan metode pengumpulan data. Jenis data yang dibutuhkan dalam penelitian ini adalah berupa data primer dan data sekunder. Data primer adalah data yang diperoleh secara langsung dari sumber aslinya. Data primer dapat berupa jawaban yang diperoleh dari hasil dokumentasi, kuesioner, dan wawancara atau tanya jawab secara langsung. Wawancara merupakan salah satu cara pengumpulan data primer.

Wawancara digunakan sebagai teknik pengumpulan data apabila peneliti ingin melakukan studi pendahuluan untuk menentukan permasalahan yang akan diteliti, tetapi juga dilakukan apabila peneliti ingin mengetahui sesuatu dari responden yang lebih mendalam. Data yang diperoleh dengan mewawancarai informan yaitu pengurus LMI Madiun dan mustahiq yang memperoleh dana zakat produktif dari LMI Madiun.

Data sekunder adalah data yang telah dikumpulkan oleh pihak lain. Data sekunder dari peneltian ini diperoleh dar internet, jurnal, buku serta sumber lain yang berkaitan dengan penelitian ini.

\section{E. Prosedur Pengumpulan Data}

Proses pengumpulan data merupakan langkah yang paling utama dalam penelitian. Pada penelitian ini, dipilih teknik pengumpulan data observasi langsung, wawancara, dan dokumentasi karena diharapkan untuk mendapatkan data yang berkualitas baik dan sesuai dengan kebutuhan penelitian.

\section{F. Teknik Pemeriksaan Keabsahan Data}

Pada tahap ini, dilakukan pemeriksaan keabsahan pada data yang telah diperoleh selama proses pengumpulan data. Pada penelitian ini, teknik yang digunakan adalah teknik triangulasi sumber. Teknik ini dipilih sebagai uji keabsahan data yang paling sesuai untuk membantu menghasilkan jawaban penelitian yang sahih dan dapat dipertanggungjawabkan dari segala segi. Menurut Patton (1987: 331) dalam Moleong (2001: 178) menjelaskan, "Triangulasi dengan sumber berarti membandingkan atau mengecek balik derajat kepercayaan suatu informasi yang diperoleh melalui waktu dan alat yang berbeda dalam metode kualitatif".

Pengecekan keabsahan data ini dapat dilakukan dengan membandingkan data hasil pengamatan dengan data hasil wawancara ataupun membandingkan hasil wawancara dengan isi suatu dokumen yang berkaitan. Pada penelitian ini, akan dilakukan pembandingan keselarasan antara hasil wawancara dengan pihak terkait, hasil observasi, dan hasil dokumentasi yang didapat selama proses pengumpulan data.Dari pembandingan tersebut akan diperoleh hasil penelitian yang akurat dan dapat dipertanggungjawabkan kebenarannya.

\section{G. Teknik Analisis}


Rulloh, et al/ Jurnal Ekonomi Syariah Teori dan Terapan Vol. 5 No. 3 Maret 2018: 184-199;

\section{DAMPAK PENDAYAGUNAAN DANA ZAKAT PRODUKTIF TERHADAP KEBERHASILAN USAHA KECIL MENENGAH MUSTAHIQ (STUDI KASUS LMI MADIUN)}

Pada tahap ini, setelah melakukan pengumpulan data, maka data tersebut dianalisis untuk mendapatkan kesimpulan. Yin (2009:133) menjelaskan bahwa terdapat tiga macam bentuk teknik analisis yang dapat digunakan dalam penelitian studi kasus antara lain penjodohan pola, pembuatan penjelasan dan analisis deret waktu.

1. Penjodohan pola (patter matching) Teknik analisis penjodohan pola yaitu menggunakan logika penjodohan pola. Logika seperti ini membandingkan pola yang didasarkan pada data empiris dengan pola yang diprediksi atau dengan beberapa prediksi alternatif. Jika kedua pola ini memiliki persamaan, hasilnya dapat menguatkan validitas studi kasus yang bersangkutan.

2. Pembuatan penjelasaan (explanation buildig)

Teknik analisis ini bertujuan untuk menganalisis data studi kasus dengan cara membuat suatu penjelasan tentang kasus yang bersangkutan untuk keberlanjutan studi

3. Analisis Deret Waktu (time series analysis)

Teknik analisis deret waktu hampir sama dengan teknik penjodohan pola. Perbedaannya terletak pada pola yang dijodohkan. Analisis deret waktu lebih menekankan pada prosedur atau kronologis suatu peristiwa (pendekatan eksperimen). Jika hasil penelitian menunjukkan hasil yang tidak sama dengan kronologis yang ditetapkan berdasarkan bukti empiris atau teori, maka hasil tersebut tidak signifikanfakta yang terjadi di lokasi penelitian dalam bentuk tulisan.

Menurut penjelasan di atas, penelitian ini menggunakan teknik analisis penjodohan pola (pattern matching). Pembahasan dilakukan dengan cara membahas dampak pendayagunaan dana zakat produktif kepada mustahiq yang diberikan oleh LMI Madiun dengan fokus utama terhadap keberhasilan usaha yang dijalankan oleh mustahiq, apatah usaha yang dijalankan mustahiq mengalami keberhasilan setelah mendapatkan bantuan dana zakat produktif. Indikator yang digunakan dalam mengukur keberhasilan usaha mustahiq adalah peningkatan modal, peningkatan pendapatan, peningkatan produksi dan pendapatan jumlah konsumen serta peningkatan amal jariyah mustahiq. Apabila indikator tersebut terpenuhi maka dapat dikatakan bahwa usaha yang dijalankan mustahiq berhasil. Sebaliknya, tidak ada peningkatan salah satu atau lebih dari kelima indikator tersebut maka usaha yang dijalankan mustahiq belum bisa dikatakan berhasil.

Langkah terakhir adalah proses penyajian data berupa interpretasi hasil wawancara dalam sebuah narasi deskriptif sehingga dapat dengan 
Rulloh, et al/ Jurnal Ekonomi Syariah Teori dan Terapan Vol. 5 No. 3 Maret 2018: 184-199;

DAMPAK PENDAYAGUNAAN DANA ZAKAT PRODUKTIF TERHADAP KEBERHASILAN USAHA KECIL MENENGAH MUSTAHIQ (STUDI KASUS LMI MADIUN)

mudah dipahami oleh semua pihak yang membaca hasil penelitian ini.

\section{Hasil dan Pembahasan}

\section{A. Validitas Data Penelitian}

Seperti yang dijelaskan pada Bab 3, penulisan pada bab ini telah dilakukan pemeriksaan keabsahan data dengan menggunakan triangulasi sumber, yaitu membandingkan atau mengecek keselarasan antara hasil wawancara dengan pihak terkait, hasil observasi, dan hasil dokumentasi yang didapat selama proses pengumpulan data. Pada penelitian ini dilakukan pengecekan data dengan cara mengajukan research questions kepada ketiga informan yang mendapatkan bantuan dana zakat produktif, sehingga akan memperkuat dan menambah derajat kepercayaan penemuan hasil penelitian. Data yang diperoleh dari observasi langsung, wawancara, dan dokumentasi menghasilkan gambaran penelitian yang konsisten. Dari pembandingan tersebut akan diperoleh hasil penelitian yang akurat dan dapat dipertanggungjawabkan kebenarannya.

\section{B. Analisis dan Pembahasan}

1. Peningkatan Modal

Modal usaha adalah mutlak diperlukan untuk melakukan kegiatan usaha. Soewartoyo (1992:14) menjelaskan bahwa modal adalah sejumlah uang atau barang yang digunakan untuk kegiatan usaha. Dari penjelasan tersebut modal usaha dapat berupa vang tunai maupun beupa alat kerja. Besar kecilnya modal yang dibutuhkan tergantung dari besar kecilnya usaha yang dijalankan. Sumber modal usaha dapat diperoleh dari modal sendiri, bantuan pemerintah, lembaga keuangan baik bank dan lembaga keuangan non bank. Besar kecilnya modal akan mempengaruhi perkembangan usaha dalam pencapaian pendapatan.

hasil penelitian menunjukkan bahwa para informan yang menerima bantuan dana zakat produktif dari LMI Madiun menyatakan bahwa modal usaha yang digunakan saat ini meningkat. Modal yang diberikan LMI Madiun kepada informan ada yang berupa vang tunai dan ada yang berupa alat kerja. Modal usaha yang diberikan LMI Madiun sesuai dengan kebutuhan usaha mustahiq. Sehingga para mustahiq dapat dengan mudah mengembangkan usaha yang mereka jalankan karena terdapat peningkatan jumlah dana dan jumlah alat dalam proses produksi. Dengan demikian, dapat disimpulkan bahwa pendayagunaan dana zakat produktif berdampak terhadap peningkatan modal usaha mustahiq.

\section{Peningkatan Pendapatan}

Indikator keberhasilan usaha yang kedua adalah peningkatan pendapatan. Tujuan utama dari suatu usaha adalah mendapatkan pendapatan. Qardhawi (2007:458) menyatakan bahwa ekonomi Islam memandang "pendapatan merupakan 
Rulloh, et al/ Jurnal Ekonomi Syariah Teori dan Terapan Vol. 5 No. 3 Maret 2018: 184-199;

\section{DAMPAK PENDAYAGUNAAN DANA ZAKAT PRODUKTIF TERHADAP KEBERHASILAN USAHA KECIL} MENENGAH MUSTAHIQ (STUDI KASUS LMI MADIUN)

hasil yang diperoleh dari melakukan setiap usaha, baik berupa uang, barang dan hasil yang lainya". Pendapatan seseorang harus dapat digunakan untuk menentukan tingkat kesejahteraan sebab pendapatan seseorang akan dapat memenuhi kebutuhan hidupnya sehari-hari baik secara langsung maupun tidak langsung. Salah satu faktor yang mempengaruhi tingkat pendapatan seseorang adalah semangat dan motivasi dalam bekerja.

Hasil peneilitian menunjukkan bahwa seluruh informan yang menerima bantuan dana zakat produktif dari LMI Madiun mengalami peningkatan pendapatan. Terdapat satu informan tidak dapat menyatakan berapa jumlah pendapatan karena setiap ada pemasukan langsung dibelanjakan untuk membeli bahan-bahan jualan. Pendapatan yang dimaksud dalam penelitian ini adalah pendapatan kotor. Penggunaan pendapatan kotor ini disebabkan oleh mayoritas informan mengalami kesulitan dalam membuat perhitungan atau laporan keuangan. Walaupun demikian mereka merasakan laba usaha yang dijalankan saat ini sedikit meningkat dibanding sebelumnya.

Peningkatan pendapatan usaha mustahiq juga tidak lepas dari peran LMI Madiun dalam memberikan pengawasan dan pendampingan berupa motivasi kepada informan agar terus bersemangat dalam menjalankan usaha. Dengan demikian, dapat disimpulkan bahwa pendayagunaan dana zakat produktif berdampak terhadap peningkatan pendapatan mustahiq.

\section{Peningkatan Produksi}

Indikator keberhasilan usaha yang ketiga adalah peningkatan produksi. Ahman (2004:116) menjelaskan bahwa "produksi adalah suatu kegiatan yang dilakukan oleh manusia untuk menghasilkan barang-barang dan jasa serta menambah manfaat suatu barang".

menunjukkan bahwa seluruh informan mustahiq yang menerima bantuan dana zakat produktif dari LMI Madiun mengalami peningkatan produksi. Peningkatan produksi yang terjadi pada semua informan dapat dilihat dari perkembangan usaha mustahiq, peningkatan barang dan jasa yang diproduksi serta penambahan bahan baku. Dari sisi perkembangan usaha mustahiq, hampir semua usaha yang dijalankan mustahia berkembang. Ada yang dulu hanya berjualan kue sekarang mempunyai toko klontong dan ada yang mempunyai usaha baru seperti usaha sablon.

Semua informan menyatakan bahwa bahan baku untuk proses produksi meningkat. Peningkatan ini disebabkan jumlah produksi barang dan jasa meningkat. Dengan demikian, dapat disimpulkan bahwa pendayagunaan 
Rulloh, et al/ Jurnal Ekonomi Syariah Teori dan Terapan Vol. 5 No. 3 Maret 2018: 184-199;

DAMPAK PENDAYAGUNAAN DANA ZAKAT PRODUKTIF TERHADAP KEBERHASILAN USAHA KECIL MENENGAH MUSTAHIQ (STUDI KASUS LMI MADIUN)

dana zakat produktif berdampak terhadap peningkatan produksi.

\section{Peningkatan Jumlah Konsumen}

Indikator keberhasilan usaha yang keempat adalah peningkatan jumlah konsumen. Tatik Suryani (2003:12) menjelaskan bahwa "konsumen adalah setiap orang pemakai barang atau jasa yang tersedia dalam masyarakat, yang digunakan untuk kepentingan diri sendiri, kelvarga dan orang lain yang tidak untuk diperdagangkan".

Hasil penelitian menunjukkan bahwa seluruh informan mustahia yang menerima bantuan dana zakat produktif dari LMI Madiun mengalami peningkatan jumlah konsumen. Para informan mengatakan bahwa konsumen mereka bertambah banyak dari sebelumnya. Seperti halnya usaha toko klontong yang pembeli bertambah banyak dan pembeli berasal dari lingkungan setempat yang umumnya adalah anak-anak kecil. Untuk usaha laundry konsumen yang menggunakan jasanya sudah ada yang berasal dari luar lingkungan rumah bahkan sampai luar Desa. Untuk usaha keset cantik sudah mampu memperluas daerah pemasaranya sampai luar Kota Madiun. Pembelinya ada yang berasal dari daerah Ponorogo, Magetan dan Ngawi. Dengan demikian, dapat disimpulkan bahwa pendayagunaan dana zakat produktif berdampak terhadap peningkatan jumlah konsumen.

\section{Peningkatan Amal Jariyah}

Indikator keberhasilan usaha kellima adalah peningkatan amal jariyah mustahiq. Amal jariyah adalah amal yang pahalanya akan terus mngalir dan tidak akan putus pahalanya meskipun orang yang beramal sudah meninggal dunia. Amal jariyah terbagi menjadi tiga yaitu sedekah jariyah, ilmu yang bermanfaat dan anak yang shaleh.

Hasil penelitian menunjukkan bahwa seluruh informan mustahia yang menerima bantuan dana zakat produktif dari LMI Madiun mengalami peningkatan dalam beramal jariyah baik dalam bersedekah maupun berinfaq. Setiap informan dalam bersedekah berbeda-beda dalam memberikanya. Ada yang berupa makanan ringan, vang tunai dan sembako. Sedekah yang diberikan masing-masing informan sesuai dengan kelebihan harta yang dimilikki.

Semua informan dalam membayar infaq sudah mampu setiap satu bulan sekali kepada pihak LMI Madiun. Pihak LMI Madiun selain memberikan bantuan dana zakat produktif juga memberikan wawasan dan pengetahuan kepada para mustahiq untuk menyisihkan dan memberikan sebagian dari pendapatan untuk diberikan kepada orang lain. Dana infaq dari mustahiq yang menerima bantuan dana zakat produktif tersebut akan disalurkan oleh pihak LMI Madiun untuk pembangunan rumah tahfid. Dengan demikian, dapat disimpulkan bahwa pendayagunaan dana zakat 
Rulloh, et al/ Jurnal Ekonomi Syariah Teori dan Terapan Vol. 5 No. 3 Maret 2018: 184-199;

\section{DAMPAK PENDAYAGUNAAN DANA ZAKAT PRODUKTIF TERHADAP KEBERHASILAN USAHA KECIL MENENGAH MUSTAHIQ (STUDI KASUS LMI MADIUN)}

produktif berdampak terhadap

peningkatan amal jariyah.

\section{v. Hasil Pembahasan}

Hasil penelitian menunjukkan ketiga informan mengalami keberhasilan dalam menjalankan usahanya. Keberhasilan usaha informan dapat dilihat dari peningkatn modal, peningkatan pendapatan, peningkatan produksi, peningkatan jumlah konsumen dan peningkatan amal jariyah. Para informan merasakan adanya perubahan skala dalam usaha yang dijalankan dan perubahan pada kondisi perekonomian keluarga yang lebih baik dari sebelumnya, seperti mampu menyisihkan sebagian hasil harta untuk bersedekah dan mampu membayar infaq secara rutin.

\section{DAFTAR PUSTAKA}

Ahman, Eeng. 2004. Ekonomi. Bandung: Grafindo Media Pratama

Antonio, Muhammad Syafi'i. 2001. Bank Syariah dar iTeori ke Praktik. Jakarta: Gema Insani.

Bariadi, Lili, Muhammad Zen, M. Hudri. 2005. Zakat dan Wirausaha. Jakarta: Centre For Entrepreneurship Development.

Chamdan, Suyatno Purnama. 2010. Motivasi dan Kemampuan Usaha dalam Meningkatkan Keberhasilan Usaha Industri Kecil (Studi Pada Industri Kecil Sepatu di Jawa Timur). Jurnal Manajemen dan Kewirausahaan. 179

Fadhillah, Diah Nur. 2012. Analisis Penyerapan Tenaga Kerja Pada Industri Kecil (Studi Kasus di Sentra Kecil Ikan Asin di Kota Tegal). Skripsi tidak diterbitkan. Semarang FEB Universitas Diponegoro

Hafidhoh. 2015. Pengaruh Pemanfaatan Dana Zakat Produktif Terhadap Tingkat Penghasilan Mustahik di Pos Keadilan Peduli Umat (PKPU) Yogyakarta. Skripsi tidak diterbitkan. Yogyakarta Fakultas Dakwah dan Komunikasi UIN Sunan Kalijaga

Moleong, Lexy J. 2001. Metodologi Penelitian Kualitatif. Edisi Revisi. Bandung: Remaja Rosda Karya.

Noersaongko, Edi. 2005. Analisis Pengaruh Karakteristik Individu, Kewirausahaan dan Gaya Kepemimpinan Terhadap Kemampuan Usaha serta Keberhasilan Usaha Pada Usaha Kecil Batik di Jawa Tengah. Malang: Skripsi Universitas Merdeka Malang.

Noor, Hendry Faisal. 2007. Ekonomi Manajerial. Jakarta: PT. Raja Grafindo Persada

Primiana, Ina. 2009. Menggerakan Sektor Rill dan Industri. Bandung: Alfabeta

Qadir, Abdurrahman. 2011. Zakat dalam Dimensi Mahzab dan Sosial. Jakarta: PT.Grafindo Persada.

Qardhawi, Yusuf. 1999. Hukum Zakat (Terjemahan). Jakarta: PT Pustaka Litera Antar Nusa.

2007. Hukum Zakat (Terjemahan). Jakarta: PT Pustaka Litera Antar Nusa

Ryanti, Benedicta Prihatin Dwi. 2003. Kewirausahaan dari Sudut Pandang Psikologi Kepribadian. Jakarta:Grasindo

Sasono, Adi. 1998. Solusi Islam Atas Problematika Umat: Ekonomi, Pendidikan dan Dakwah. Jakarta:Gema Insani Press

Shinta Dwi Wulansari. 2014. Analisi Peranan Dana Zakat Produkif Terhadap Perkembangan Usaha Mikro Mustahiq (Penerima Zakat) (Studi Kasus Rumah 
Rulloh, et al/ Jurnal Ekonomi Syariah Teori dan Terapan Vol. 5 No. 3 Maret 2018: 184-199;

DAMPAK PENDAYAGUNAAN DANA ZAKAT PRODUKTIF TERHADAP KEBERHASILAN USAHA KECIL MENENGAH MUSTAHIQ (STUDI KASUS LMI MADIUN)

Zakat Kota Semarang). Semarang:

Jurnal Ekonomi Universitas Diponegoro

Soewartoyo, dan Lumbantoruan. 1992.

Ensiklopedia Ekonomi, Bisnis, dan

Manajemen Jilid I. Jakarta: PT Citra.

Sugiyono. 2009. Metode Penelitian Bisnis (Pendekatan Kuantitatif, Kualitatif, dan R\&D). Bandung: Penerbit Alfabeta.

Suryani, Tatik. 2003. Perilaku Konsumen Edisi Pertama. Yogyakarta: Graha Ilmu.

Yin, Robert K. 1988. Case Study Research Design and Methods (Applied Social Research Methods Series). Vol. 5 Revised Edition. London: SAGE Publications.

2009. Studi Kasus, Desain dan Metode Ed 1. Jakarta: Rajawali Press. 